Viktoriya V. ZHELYAZKOVA,

candidate of Philology (PhD), Associate Professor, Department of General and Applied Linguistics of Mykolaiv

Sukhomlinsky National University; 24 Nikolskaya str., Mykolaiv, 54030, Ukraine; tel.: +38 0669217141 ;

e-mail: olya.zhelyazkova@mail.ru; ORCID ID: 0000-0003-2465-7675

\title{
LINGUISTIC SEMIOTIC MARKERS OF MOVIE “AURORA» DIALOGUES BY OKSANA BAYRAK
}

Summary. This article is devoted to the linguistic semiotic analysis of movie dialogues. Due to the fact that interest of scientists in modern linguistics to movie discourse is beginning to emerge, the author makes an attempt to solve some practical problems in this area. In particular, the author carries out a brief review of the scientific literature, which highlights the phenomenon of the concept of (movie dialogue» and leads its own definition, which has a general character. The article focuses on the linguistic semiotic analysis of the film "Aurora" by Oksana Bayrak, because the films of Ukrainian origin have not been subjected to such scientific interpretations.

The author makes conclusions based on analysis of more than 280 replicas voiced in the film, determines the linguistic and semiotic markers of oral verbal and written verbal dialogues, highlighting the diegetic and nondiegetic elements in them.

Key words: movie dialogue, movie discourse, verbal, nonverbal, diegetic element, nondiegetic element, the movie "Aurora», Oksana Bayrak.

Статтю отримано 12.01.2017 $p$.

http://dx.doi.org/10.18524/2307-4558.2017.27.107886

УДК 811.161.2’22'372'42

КАЛЕНЮК Світлана Олександрівна,

кандидат філологічних наук, доцент кафедри загальної та прикладної лінгвістики Миколаївського національного університету імені В. О. Сухомлинського; вул. Нікольська, 24, м. Миколаїв, 54030, Україна; e-mail: kalenukso@gmail.com; тел.: +38 093 2978591; ORCID ID: 0000-0002-6055-8351

\section{СЕМАНТИЧНА ГЕТЕРОГЕННІСТЬ ТЕКСТУ ТА ӤЇ КОДОВІ АКТУАЛІЗАТОРИ (НА МАТЕРІАЛІ ПОВІСТІ Т. ПРОХАСБКА „ДОВКОЛӒ ОВЕРА»)}

Анотація. Мета пропонованої наукової розвідки - з'ясувати сутність семантичної гетерогенності тексту, а також установити характер залежності між семантичною неоднорідністю тексту й кодами, що в ньому функціонують. Відповідно до цього об’єктом дослідження обрано семіотичні коди як маркери семантичної гетерогенності тексту повісті Т. Прохаська "Довкола озера", а предметом - засоби їхньої номінації. Окреслена мета та складність предмета наукової уваги зумовили необхідність у застосуванні як загальнонаукових (описового, аналітичного, узагальнення, кількісного), так і спеціальних (контекстуально-інтерпретаційного) методів. Результати роботи отримано на основі змістових експлікацій і кількісних показників. Установлено актуальні коди, що забезпечують семантичну неоднорідність тексту повісті Т. Прохаська "Довкола озера", визначено особливості номінації герменевтичних і символічних кодів із урахуванням усталених і специфічних смислів, виражених ними, здійснено лексико-семантичну характеристику узуальних та оказіональних номінацій цих кодів.

Ключові слова: семантична гетерогенність, текст, семіотичний код, узуальна номінація, оказіональна номінація.

Постановка проблеми. У твердження лінгвосеміотичного вектора в дослідженнях тексту значно розширює дебінітивне поле останнього й визначає його не лише як знакову структуру (Л. Бабенко, Я. Галло, О. Дорофеєва, І. Кочан, В. Кухаренко, Ю. Лотман, В. Лукін, В. Садченко, Б. Успенський та ін.), а і як систему кодів (Н. Андрейчук, Т. Єрохіна, Є. Івченкова, М. Лановик, В. Степанов, О. Хлєбникова, Л. Чертов та ін.). Такий ракурс з'явився в сучасній науці під упливом ідей Р. Барта, а згодом і Д. Фоккеми та У. Еко, які вперше відзначили вагому роль кодів і кодових сполук у семіотичній інтерпретації текстів чи їхніх фррагментів.

Аналіз останніх досліджень і публікацій. У цьому аспекті на сьогодні висвітлено й обгрунтовано значну кількість загальнотеоретичних положень, що стосуються насамперед з'ясування мовленнєвого потенціалу кодів як текстових складників (О. Бразговська, Дж. Ділі, Г. Почепцов, А. Соломоник, Н. Степанова та ін.), визначення типологічних різновидів цих семіотичних утворень (Р. Барт, О. Бразговська, А. Диденко, У. Еко, Х. Кафтанджиєв, В. Степанов, Д. Фоккема та ін.), установлення зв'язків із культурним універсумом (Д. Гудков, С. Денисенко, В. Красних, М. Ковшова, О. Селіванова, О. Снитко, І. Тараба, З. Чанишева та ін.).Також останнім часом усе більшої уваги наукова спільнота приділяє питанню семантичної експлікації кодів, однак наявні розробки, попри їхню беззаперечну наукову цінність для лінгвістики, присвячені переважно визначенню номінативного складу кодових одиниць лише як репрезентантів текстів певної культури, через що цілісного уявлення про 
лексико-семантичне навантаження всього існуючого розмаїття кодів поки немає (див. праці Н. Венжинович, О. Галинської, О. Дідули, Т. Леонтьєвої, Н. Шарманової, С. Шестакової, Л. Щербачук та ін.). Отже, з огляду на те, що будь-який текст (принципово гетерогенний та гетероструктурний» [8, с. 54], тобто має здатність до генерування різних за складністю та семіотичним обсягом смислів і значень, а також уважаючи, вслід за О. Хлєбниковою [9], класифікацію Р. Барта [2] найбільш доцільною для аналізу механізмів кодування текстів, виокремлюємо новий напрям дослідницьких пошуків - визначення продукованої різними кодами семантики та встановлення їхньої ролі в актуалізації семантичної гетерогенності тексту, в якому вони функціонують.

Не меншою мірою зумовлює наш інтерес до окресленої проблеми й те, що доволі високий рівень неоднорідності, в т. ч. і семантичної, мають тексти феноменологічної прози, бо ж «події в них не $\epsilon$ самодостатнім рушієм сюжету, вираженого слабко, а швидше приводами для розгортання певних мисленнєвих (або навіть перцептивно-мисленнєвих) конструктів» [5, с. 223]. Такою ознакою характеризуються твори представника феноменологічної течії постмодернізму Т. Прохаська, практично не дослідженого сучасними лінгвістами. Це увиразнює актуальність і перспективність досліджень семіотичних кодів, що впливають на семантичну гетерогенність т. зв. безподієвих текстів.

Постановка завдання. Метою пропонованої розвідки є виявлення кодових одиниць у тексті повісті Т. Прохаська “Довкола озера» й аналіз особливостей номінації найпотужніших актуалізаторів семантичної гетерогенності. Досягнення поставленої мети потребує вирішення таких завдань: 1) з'ясувати сутність семантичної гетерогенності тексту; 2) встановити залежність між семантичною неоднорідністю та кодовим наповненням тексту; 3) виявити на основі змістової експлікації кодів актуалізатори семантичної гетерогенності тексту; 4) визначити продуктивні типи номінації кодів та їхні лексико-семантичні характеристики. Об'єктом дослідження є семіотичні коди як маркери семантичної гетерогенності тексту повісті Т. Прохаська "Довкола озера), а предметом - засоби їхньої номінації.

Фактичним матеріалом став текст повісті Т. Прохаська “Довкола озера» з огляду на те, що в ній автор “пропонує певну модель творення картини світу — деталізованої, максимально суб'єктивної, з одного боку, індивідуальної, а з іншого, - універсальної, асоціативно спорідненої зі світовідчуттям кожного вдумливого реципієнта) [5, с. 227], для змалювання якої вдається до використання різнотипних кодів, яких у загальній сукупності ми забфіксували понад 280 одиниць.

Виклад основного матеріалу. У науковій літературі під семантичною гетерогенністю прийнято розуміти одну з основних властивостей тексту, що “зумовлюється поєднанням у ньому системних значень і мовленнєвих смислів» [4, с. 3]. Проте їхнє виникнення та функціонування в текстовій матерії визначається, як правило, двома факторами: з одного боку, використанням різних типів знаків, а з іншого, - закодованістю тексту [8, с. 54]. Це означає, що семантична гетерогенність тексту фіксує фокт взаємодії в ньому спочатку мовних знаків, а потім кодів, причому різнорідна мовна генеза обох і мовленнєва потужність останніх робить цей текст неоднорідним, тобто полікодовим.

Код, як свідчить огляд низки наукових праць, є багатовимірним і міждисциплінарним поняттям. Його сучасне тлумачення в галузі лінгвосеміотики сформувалося на основі узагальнення дефініцій інших наукових парадигм. Завдяки цьому в лінгвосеміотичній практиці код тлумачиться як механізм породження смислу й повідомлення, а також як знакова структура (Ю. Лотман, В. Лукін, А. Усманова); правила сполучуваності та впорядкованості знаків (Л. Чертов); оказіонально взаємооднозначна відповідність кожного знака до певного означуваного (У. Еко); метаінформація, без якої неможлива семіотична інтерпретація (Ю. Шрейдер). Беручи до уваги наведені дефініції та констатуючи неодностайність поглядів учених на сутність цього поняття, під кодом розуміємо, як пропонує Л. Чертов, сукупність знаків, поєднаних та впорядкованих між собою, бо ж саме це визначення певною мірою засвідчує, що семантика коду може детермінуватися як одним, так і кількома знаками залежно від того, як ними генеруються текстові смисли - прямо чи опосередковано.

У тексті повісті Т. Прохаська (Довкола озера) наявні перелічені вище коди, виокремлення яких ми здійснювали методом суцільної вибірки й з урахуванням таких критеріальних ознак: 1) здатність коду до транслювання прямого чи прихованого смислів; 2) наявність у структурі коду одного чи кількох знаків, що уможливлюють вираження одного зі смислів або значень. Уході аналізу ми з'ясували, що семічні (Маркус; Северин) та проайретичні (наближувати; притиснутися) коди експлікують у текстах переважно системні значення, тобто ті, що закріплені в словниках мови. Це пояснюємо здатністю цих кодів вербалізуватися переважно за допомогою одиничних мовних знаків із фіксованим (прямим і переносним) значенням. Такої властивості позбавлені герменевтичні (пам'ятаючи каміння, можна вигадувати береги; усі ці варіативні ряди не впливають на впізнавання, як порізи не переінакшують ліній долонь) та символічні (територія його мозку; найдальші закапелки тіла) коди, бо поставити проблемне питання чи утворити асоціативний ряд й інтерпретувати їхні знакові складники поза контекстом практично неможливо, через що ці коди, представлені не одним мовних знаком, експлікують здебільшого мовленнєві смисли. Особливістю гномічних кодів є їхня здатність в одних випадках передавати значення, регламентовані мовною системою, чи відбивати реалії етнокультури (небо $i$ земля, пов'ялі квітu), а в інших - імплікувати індивідуально-авторське, суголосне із загальнокультурним, світосприйняття та світорозуміння (ліс вічної осені, заћляћлість нічних 
метеликів). Відтак, наведене дозволяє говорити про структурну різнорідність, а отже, й семантичну оригінальність кодів. Зважаючи на це та враховуючи той фокт, що “полікодовий текст служить засобом репрезентації тексту як когерентного цілого, сформованого з кількох семіотичних кодів») [4, с. 4], між кодами та семантичною гетерогенністю тексту встановлюється пряма залежність: що численнішими та різноріднішими будуть коди, то вищим буде рівень неоднорідності тексту.

Як показав аналіз, у кодовій матерії тексту повісті Т. Прохаська (Довкола озера) фонкціонують понад $2 / 3$ герменевтичних і символічних кодів, що й окреслили межі семантичної неоднорідності обраної джерельної бази дослідження. Проілюструємо це з урахуванням такого параметра, як тип номінації кодів. Вибір саме цього аспекту вивчення пояснюємо тим, що кожний автор, у т. ч. i Т. Прохасько, по-своєму осмислює, описує й інтерпретує явища навколишньої дійсності, у зв'язку з чим лінгвістична характеристика кодів, що функціонують уже у створеній автором реальності, стає невіддільною від поняттєвої. Тому передача однакових смислів, що виражаються кодами, може відбуватися за допомогою різних типів номінацій. Зважаючи на те, що в лінгвістиці й досі спостерігається різновекторність критеріїв поділу номінативних одиниць (місце творення, структура, джерело появи, призначення, характер позначуваного, загальноприйнятість чи специфічність, мотивованість тощо) [1], а також ураховуючи різнорідність семіотичної ґенези кодів та їхні широкі дистрибутивні можливості, за основу семантичного опису беремо критерій загальноприйнятості чи специфічності номенів, що, на наше переконання, дасть змогу визначити, які семантичні смисли ці коди виражають - фіксовані мовою чи запропоновані самим автором. За цим критерієм, як доводять у своїх роботах Л. Азарова, Г. Лепко, М. Мігіріна, І. Нестеренко, номінація буває узуальна та оказіональна $[1$, c. 88]. Перший різновид детермінований словником мови, а другий - особливостями авторського світогляду, його компетенціями, мотивами та намірами, а також контекстом тексту [1, с. 88].

Зібраний і опрацьований нами фактичний матеріал показав, що найбільш потужними, семантично розгалуженими й активно вживаними є символічні коди (74 \%). Вони здатні виражати як узуальні, так і оказіональні значення. Логіка розподілу їх за цими групами базувалася насамперед на наявності дефініцій у Великому тлумачному словнику української мови [3], відсутність, а також і невідповідність літературній нормі яких вказувала на оказіональність досліджуваних одиниць. Крім того, не меншої уваги приділено й такому аспекту, як нашаровування на словникове значення нових елементів смислу.

Виявлено, що узуальний смисл передають символічні коди, у складі яких фонкціонують такі лексичні одиниці:

- терміни (43%): зі складною лінією берегів (затоки, урвища, мілини, фйорди, вигини, півострови) (географічний термін); вивереною назовні иастиною генома (біологічний термін); ураженого антибіотиками моху (біологічний термін);

- застарілі слова (57 \%): бастіони і борти цитаделі; у цитаделі ботанічного саду; бернардини, юри $i$ редемптористи (серед виділених слів є архаїзми й історизми: першу групу репрезентують слова (цитадель), що означає фортечну споруду, використовувану як в'язницю [3, с. 1188], та (юра», що вживається для вираження несподівано втраченої надії, припинення свободи дій тощо; другу слова (бернардин) (член католицького чернечого ордену) та (редемпторист) (католицька чоловіча монахська конгрегація 1732 р.)).

Наведені приклади показують, що письменник удається до використання термінологічної (а саме де термінологізованої) та застарілої лексики для репрезентації власних асоціацій і константів культурної пам'яті народів без бодай часткового спотворення його узуальності. Це означає, що узуальні значення символічних кодів мають загальноприйнятий характер і відтворюють систему символічних асоціацій, зрозумілих для представників різних етнічних спільнот.

Символічні коди вербалізуються й оказіональними номінаціями, що є, як показав аналіз, найчисельнішою групою цих кодів, у складі яких містяться лексеми, що виражають (нові емоційно-оцінні значення, що з'являються в слові в певному контексті на основі індивідуальних асоціацій) [7, с. 31], а також лексеми, що ілюструють умисне відхилення від літературної норми. Відповідно до цього виокремимо в тексті аналізованої повісті такі типи оказіональних символічних кодів:

- діалектизми (21 \%): иаїлися на дахах $i$ піддашшях; на пуделочках маку; кульчик студив сухожилля на шиї. Виділені слова витлумачуються у словниках так: (піддашшя» означає горище [3, с. 1150]; (пуделочко» походить від слова (пудло» та означає коробку чи фрутляр [3, с. 1188]; (кульчик) - це сережка [3, с. 596]);

- рідко вживані лексеми (10\%): керунок течї̈; пустиння та смітники (слово (керунок» означає напрям [3, с. 561], (пустиння) - занедбане обійстя [3, с. 1190]);

- розмовні слова (3 \%): між вікнами мусили лежати коци; безконечними переходами у гори (слово (коц) означає ворсовий пристиджений однобічний килим [3, с. 572], слово “безконечний» утворено від загальновживаного літературного "безкінечний», що позначає того, який не має ні початку, ні кінця, не має видимих меж; безмежний [3, с. 68]);

- оказіоналізми, що «зумовлені зміною в структурі значення слова під впливом контексту або системи образів і сприяє адекватному розумінню слова лише за умов виходу за межі його словникових значень» [3, с. 31], через це й вербалізуються, здебільшого, за допомогою кількох мовних знаків, 
що утворюють словосполучення (66 \%): рослина від нерослини; нелатина; будинки нори; будинки гнізда; втеча від дискурсу; русла рельєфу губ; лабіринти дактилоскопії; рами свідомості; всередині квітучої сфери; паном фблористичних реєстрів; неживі грані стебла; галючиначійний багатокутник; всі війни уяви; у біографіях болю, холоду і хвороби; улалки досвіду, пам'ять шкіри і постулати слизових; блористична логіка ареалу; вічнозелена конструкція пухлин; реванш флори.

Зауважимо, що перевага власне оказіоналізмів над іншими типами нелітературних лексем у блоці символічних кодів зумовлена, на нашу думку, більш потужною асоціативністю та стилістичними потенціями перших і авторськими інтенціями до вербального представлення власних асоціативних зв'язків, що виникають поза фіксованими лексикограффічними значеннями слів, а також намірами активізувати увагу й уяву читацької аудиторії. Не менш важливо сказати також і про те, що оказіональні символи забезпечують семантичну неоднорідність тексту більшою мірою, ніж узуальні.

Другу позицію в ієрархії маркерів семантичної гетерогенності аналізованого тексту займають герменевтичні коди (19 \%). Вони представлені також доволі розгалуженою системою назв, а тому в основі їхньої вербальної репрезентації лежать як узуальні, так і оказіональні значення.

Узуальні номінації герменевтичних кодів найяскравіше виражаються за допомогою загальновживаних слів, що репрезентують різні тематичні групи слів, а також стилістичні засоби, серед яких головними визначено такі:

- номінативно-ланцюжкові повтори (44 \%), за яких (послідовний розвиток думки відбувається так, що в першому реченні повідомляється про певну подію, явище, а кожне наступне щось додає нове. Граматично ланцюговий зв'язок виявляється в застосуванні лексичного повтору, синонімічних замін і вказівних займенникових слів, співвідносних з іменами предметно-понятійного змісту» [цит. за 10]: притлумлюєш пам'ять, шоб не пам'ятати ультраструктур; можна думати про те, як ні про шо не думається; те, шо минає, не є минулим;

- антоніми (56 \%): багатоколірна суміш галужень стягувалася $і$ розтягалася; при сприятливому сходові ии заходові сонця $і$ мудрому розмішенні дзеркал крізь нъого можна проглядати; не переставало вібрувати через прояснення ии ватемнення тепер вже невиразного жовтого освітлення з глибини кімнат; спочатку піч захолодна, а при кінці буде загарячою для дотику; життя ніколи не буває замале, в будь-якій тривалості воно є повністю.

Оказіонально маркованими є герменевтичні коди, утворені за допомогою таких засобів:

- тотожні лексичні повтори (50 \%): звички стають сенсом $i$ підставою у житті, позбавленому сенсу $i$ підстав; до жінки, якою $є$ всі інші жінки по-різному; внутрішній світ людини - те, иоо тепер на внутрішньому бочі повіки;

- антоніми (50 \%): приходити вночі за картою денних відкриттів; уможливлюючи неможливе; гіркість уможливлює відчутність усіх шарів власного тіла - стислого $i$ розпертого одночасно.

Висновки. Кількісний розподіл узуальних і оказіональних герменевтичних кодів дає підстави говорити про те, що перша група є найбільш актуальною в семіотичній площині тексту. У зв'язку з цим констатуємо, що складність герменевтичних кодів виявляється не в утрудненій інтерпретації його окремих складників, а в процесі декодування загальної інформації, що ними передається, бо вона, як правило, має філософський підтекст. Тому ці коди характеризуються здатністю урізноманітнювати семантику текстових смислів.

Низьку частотність уживання фіксуємо серед проайретичних $(4 \%)$, гномічних (2\%) і семічних (1 \%) кодів. Зважаючи на поодинокі випадки вживання цих типів кодових сполук, відзначаємо їхню нерелевантність у забезпеченні семантичної гетерогенності тексту досліджуваної повісті.

Отже, в тексті повісті Т. Прохаська (Довкола озера) функціонують різні типи кодових одиниць мови, проте найбільш потужними актуалізаторами його семантичної гетерогенності визначено символічні та герменевтичні коди. Це може бути пов'язано з наявністю в них такого квантора спільності, як здатність до репрезентації прихованого смислу слова чи фррази або натяк на нього. Саме ця властивість, за нашими спостереженнями, виступає інтегральною ознакою під час номінації кодів. $\mathrm{У}$ цьому аспекті вони можуть бути представлені узуальними й оказіональними номінаціями. Серед символічних кодів узуальні номінації представлено термінами та застарілими словами; оказіональні - діалектизмами, рідко вживаними, розмовними й оказіональними словами. 3 числа герменевтичних кодів узуальними виявилися номінативно-ланцюжюові повтори й антоніми, а оказіональними тотожні лексичні повтори й антоніми також.

Перспективу подальших досліджень убачаємо в здійсненні комплексного семантичного аналізу кодів та поділі їх на тематичні групи. 


\section{Лiтература}

1. Азарова Л. Визначення типів номінації в сучасному мовознавстві / Л. Азарова, Г. Лепко // Рідний край : альманах Полтавського національного педагогічного університету ім. В. Г. Короленка. — 2010. - № 22 (1). - Полтава, 2010. - C. 86-90.

2. Барт Р. S / Z / Пер. с фр. Г. К. Косикова и В. П. Мурат ; под ред. Г. К. Косикова. - 3-е изд. / Р. Барт. - М. : Академ. Проект, 2009. - 373 с.

3. Великий тлумачний словник сучасної української мови : 170000 слів / уклад., гол. ред. В. Т. Бусел. - К. ; Ірпінь : Перун, 2003. - 1427 с.

4. Галло Я. К проблематике семантической гетерогенности текста / Я. Галло // Opera Slavica. Slavisticke Rozhledy. - Brno, 2013. - Fasc. XXIII (2). - C. 1-6.

5. Гребенюж T. В. Характерні риси подієвості феноменологічної прози (на матеріалі творів Т. Прохаська) / Т. В. Гребенюк // Наук. записки Бердянського держ. пед. університету. - 2015. - Вип. 5. - С. 221-228. 40 .

6. Прохасько Т. Довкола озера / Прохасько Т. // Лексикон таємних знань. - Львів : Кальварія, 2003. - С. 29-

7. Стадній A. C. Оказіональні й узуальні конотативні значення дієслів у мові сучасних ЗМІ / А. С. Стадній // Мовознавчий вісник : зб. наук. пр. / МОН України ; Черкаський нац. ун-т ім. Б. Хмельницького; відп. ред. Г. І. Мартинова. - Черкаси, 2014. - Вип. 18. - С. 30-34.

8. Теория текста : учеб. пособие / Ю. Н. Земская, И. Ю. Качесова, Л. М. Комиссарова, А. А. Чувакин и др. М. : Флинта, Наука, 2010. - 132 с.

9. Хлебникова О. В. Семиотические коды в философрком тексте [Электронный ресурс] / О. В. Хлебникова // Вестник Омского государственного педагогического университета. - 2006. - Режим доступа : http://www.omsk. edu/article/vestnik-omgpu-11.pdf ; Название с экрана.

10. Чередніченко А. Повтори як засіб когезії тексту [Електронний ресурс] / А. Чередніченко // Режим доступу : http://synopsis.kubg.edu.ua/index.php/synopsis/article/view/91; Назва з екрану.

\section{References}

1. Azarova, L., Lepko, G. (2010), "Determining the type of a nomination in modern linguistics», Native Land : Almanac of Poltava V. G. Korolenko National Pedagogical University ["Vyznachennia typiv nominacij v suchasnomu movoznavstvin, Ridnyj kraj : Al'manakh Poltavs'kogo nacional'nogo pedagogichnogo universytetu im. V. G. Korolenka], Poltava, vol. 22, part 1, pp. 86-90.

2. Bart, R. (2009), S / Z, Academic Project, Moscow, 373 p.

3. Great Dictionary of the Modern Ukrainian Language (2003) [Velykyj tlumachnyj slovnyk suchasnoji ukrajins'koji movy], Perun, Irpen-Kyiv, 1427 p.

4. Gallo, Ya. (2013), "To the problems of semantic text heterogeneity», Opera Slavica. Slavisticke Rozhledy ["K problematike semanticheskoj geterogennosti teksta», Opera Slavica. Slavisticke Rozhledy], Brno, vol. XXIII (2), pp. $1-6$.

5. Grebeniuk, T. (2015), "Characteristics eventfulness of phenomenological prose (based on the works by T. Prokhasko)», Scientific Notes of Berdyansk State Pedagogical University [ [Harakterni rysy podievosti fenomenologichnoji prozy (na materiali tvoriv T. Prokhaska)", Naukovi zapysky Berdyans'kogo derzhavnogo pedagogichnogo universitetu], Berdyans'k, vol. 5, pp. 221-228.

6. Prokhasko, T. (2003), "Around the Lake», The Lexicon of secret knowledge [“Dovkola ozera”, Лексикон таємних знань], Calvarija, Lviv, pp. 29-40.

7. Stadnij, A. "Usual and occasional connotative meaning of verbs in the language of contemporary media", Linguistic Bulletin : Collected Works ["Okazionalni j uzualni konotatyvni znachennia diesliv u movi suchasnykh ZMI», Movoznavchyj visnyk : zbirnyk naukovykh prac'], Cherkassy B. Khmelnitsky National University, Cherkassy, vol. 18, pp. 30-34.

8. Theory of Text : Textbook, (2010) [Teorija teksta : ucheb. posobie], Flinta, Nauka, Moscow, 132 p.

9. Khlebnikova, O. "Semiotic codes in a philosophical text» ["Semioticheskie kody v filosofskom tekste»], available at: http://www.omsk.edu/article/vestnik-omgpu-11.pdf [Accessed 13 Jan. 2017].

10. Cherednichenko, A. "Repeat as means of text cohesive» [(Povtory yak zasib koheziyi tekstu»], available at: http:// synopsis.kubg.edu.ua/index.php/synopsis/article/view/91 [Accessed 14 Jan. 2017].

\section{КАЛЕНЮК Светлана Александровна,}

кандидат филологических наук, доцент кафедры общей и прикладной лингвистики Николаевского национального университета имени В. А. Сухомлинского; ул. Никольская, 24, г. Николаев, 54030, Украина; тел.: +38 093 2978591; e-mail: kalenukso@gmail.com; ORCID ID: 0000-0002-6055-8351

\section{СЕМАНТИЧЕСКАЯ ГЕТЕРОГЕННОСТЬ ТЕКСТА И ЕЁ КОДОВЫЕ АКТУАЛИЗАТОРЫ (НА МАТЕРИАЛЕ ПОВЕСТИ Т. ПРОХАСЬКО „ВОКРУГ ОЗЕРА»)}

Аннотация. Целью статьи является определение сущности семантической гетерогенности текста, а также установление характера зависимости между семантической неоднородностью текста и кодами. В соответствии с этим объектом исследования стали семиотические коды как маркеры семантической гетерогенности текста повести Т. Прохасько "Вокруг озера», а предметом - средства их номинации. Указанная цель и сложность предмета научного внимания стали причиной обращения к методам общенаучным (анализ, синтез, описание, количественный) и специальным (контекстуально-интерпретационный). Результаты работы получены на основе содержательных экспликаций и количественных показателей. Установлены актуальные коды, обеспечивающие семантическую неоднородность текста повести Т. Прохасько «Вокруг озера», определены особенности номинации герменевтических и символических 
кодов с учётом сложившихся и специфических смыслов, выраженных ими, а также осуществлена лексико-семантическая характеристика узуальних и окказиональных номинаций этих кодов.

Ключевые слова: семантическая гетерогенность, текст, семиотический код, узуальная номинация, окказиональная номинация.

\section{Svitlana 0. KALENUK,}

candidate of Philology (Phd), Associate Professor, Department of General and Applied Linguistics, Mykolaiv Sukhomlinskiy National University; 24, Nikolska str., Mykolaiv, 54030, Ukraine; tel.: +38 0932978591 ; e-mail: kalenukso@gmail.com; ORCID ID: 0000-0002-6055-8351

\section{HETEROGENEITY SEMANTIC TEXT AND ACTUALIZERS CODE (ON THE MATERIAL OF THE NOVEL "AROUND THE LAKE" BY T. PROKHASKO)}

Summary. The semantic heterogeneity of the text has always been the object of linguistic researches. Many scientists have claimed that the words and phrases are stimulants of semantic heterogeneity. But with the advent of lingvosemiotic and popularity of semiotic analysis of linguistic units, we attempted to analyze the impact of semiotic codes on the semantic heterogeneity of the text (on the material of the novel by T. Prokhasko "Around the Lake"), which until then had not been undertaken in science. In this regard, we have decided the following tasks: indentified the essence of the concept of the semantic heterogeneity of the text, established a direct relationship between the semantic heterogeneity of text and codes that it operate, on the basis of semantic explications and quantitative indicators analyzed the relevant codes that enable and affect the degree of semantic heterogeneity of text of novel by T. Prokhasko "Around the Lake». As a result we found that the most powerful actualizers of the semantic heterogeneity of the text were symbolic and hermeneutic codes. We noticed that the hermeneutic and symbolic codes are presented in the text with the help of usual and occasional nominations. Moreover, the lexical-semantic analysis of these nominations showed that in the system of symbolic codes dominated the occasionalisms, in block of hermeneutic codes - usual type of naming. This we explain the individual intentions of the author.

Key words: semantic heterogeneity, text, semiotic code, usual nomination, occasional nomination.

Статтю отримано 30.01.2017 $p$.

http://dx.doi.org/10.18524/2307-4558.2017.27.107902

УДК 811.111'367.32'271.12:177.7

\section{КИВЕНКО Инна Александровна,}

старший преподаватель кафедры профессионального английского языка Одесского национального морского университета; ул. Мечникова, 34, г. Одесса, 65029, Украина; тел. : +38 093 7937627;

e-mail: innakivenko@yandex.ru; ORCID ID: 0000-0003-2044-5456

\section{ПЕРФОРМАТИВНАЯ ПАРАДИГМА ВЫСКАЗЫВАНИЙ БЛАГОДАРНОСТИ (НА МАТЕРИАЛЕ АНГЛОЯЗЫЧНОГО ЛИТЕРАТУРНОГО ДИСКУРСА)}

Аннотация. Цель настоящей статьи - описать перформативную парадигму высказываний благодарности в англоязычном литературном дискурсе. Объект исследования - англоязычный литературный изображённый дискурс. Предмет изучения - речевой акт благодарности. Результатом работы стал анализ понятия (перформатив" и выявление свойств перформативных высказываний. Кроме того, описаны понятия (семантический перформатив» и (коммуникативно-семантическая группа». Составлена коммуникативно-семантическая группа англоязычных высказываний, объединённых интенциональным значением и иллокутивной функцией благодарности, описаны модели их реализации в речи. Дифференцированы понятия эксплицитного и имплицитного перформативов. Все перечисленные термины рассмотрены применительно к речевому акту благодарности.

Выводы. Речевой акт благодарности следует считать перформативным речевым актом. Формулы его выражения: I thank you, Thank you, Thanks. Thank you и Thanks являются неполными эллиптическими предложениями с вакономерным отсутствием дейктических актантов, что является характерным для устной разговорной речи. Другие способы выражения благодарности образуют коммуникативно-семантическую группу, включающую как прямые, так и косвенные конвенциональные семантические перформативы благодарности, интенция которых легко прочитывается адресатом в определённых экстралингвальных обстоятельствах.

Практическое применение результатов исследования определяется возможностью использования теоретических положений проведённого исследования в курсах лекций и на семинарах, посвящённых проблемам теории речевых актов.

Ключевые слова: перформатив, семантический перформатив, речевой акт, благодарность, коммуникативно-семантическая группа. 